\title{
Influence of physiological stage and parity on energy, nitrogen and mineral metabolism parameters in the Ouled Djellal sheep in the Algerian Southeast arid area
}

\author{
DEGHNOUCHE K. ${ }^{1 *}$, TLIDJANE M. $^{2}$, MEZIANE T. ${ }^{2}$ and TOUABTI A. ${ }^{3}$ \\ ${ }^{1}$ Department of Agronomy, Mohamed Kheider University, Biskra 07000, Algeria. \\ ${ }^{2}$ Department of Veterinary, Hadj Lakhder University, Batna 05000, Algeria. \\ ${ }^{3}$ Biochemistry Laboratory, CHU Setif 19000, Algeria.
}

Accepted 8 January, 2010

\begin{abstract}
Investigations were conducted to determine the influence of physiological stage and parity on some indicators of energy, nitrogen and mineral metabolisms in sheep Ouled Djellal living in the Algerian Southeast arid area. The study was carried out on $\mathbf{1 0 0}$ clinically healthy multiparous and primiparous ewes, aged 2 to 7 years. The animals were divided into three ewe groups: Pregnant (P), lactating (L), and empty (E). Biochemical analysis of blood samples concerned the determination of the values of 11 metabolites [glucose, cholesterol, triglycerides, urea, total protein, albumin, calcium (Ca), phosphates $\left(\mathrm{PO}_{4}\right)$, sodium $(\mathrm{Na})$, potassium $(\mathrm{K})$, and magnesium $\left.(\mathrm{Mg})\right]$. The results showed that pregnant ewes and multiparous ones have the lowest blood glucose levels and the highest proteinemia. However, the lowest total protein and albumin values were found in empty sheep. Cholesterol and triglyceride levels were the highest in lactating and primiparous ewes. In this study, the most important calcium levels were recorded in lactating ewes which showed the lowest magnesium levels. The pregnant ewes had the highest sodium levels and low phosphatemia. Potassium levels were comparable in all animals. Statistical analysis showed that the physiological stage has a significant influence $(p<0.05)$ on serum glucose, triglycerides, phosphorus and potassium levels and a highly significant effect $(p<0.001)$ on urea, and magnesium levels. No parity effect has been observed in our study.
\end{abstract}

Key words: Ouled Djellal ewes, physiological stage, parity, energy, nitrogen, mineral metabolisms.

\section{INTRODUCTION}

Gestation and lactation are the two most critical periods in sheep feeding. The energy requirements of pregnant ewes increase significantly towards the end of gestation, during which 70 to $80 \%$ of foetal growth occurs (Sormunen-Cristian and Jauhiainen, 2001). Similarly, during the first 2 weeks of lactation, the export of nitrogen and energy in milk is very high and the animals can not ensure it without the mobilization of their reserves (Tissier and Thériez, 1978). Ewes should be in good health during and after pregnancy so as to produce viable lambs.

The identification of metabolism change of such sheep in various reproduction phases, the determination of metabolic blood profiles, including serum mineral and biochemical parameters is necessary to study ruminant metabolism disorders and can provide useful information on the animal nutritional status (Balikci et al., 2007). Correspondingly, mineral content and biochemical 
indicators in the blood of sheep are widely used (Sykes and Field, 1974; Hajdarevié et al., 1989).

A significant number of authors describe the mineral and biochemical indicators in the blood of the sheep (Pastrana et al., 1991a, b; Shinde et al., 1995; Klinkon and Zadnik, 1997) reported by Antunovié et al. (2004). But, only a very small number of authors report about the influence of the reproductive status (Baumgartner and Penthaner, 1994; Ramos et al., 1994; EL-Sherif and Assad, 2001; Antunovié et al., 2002, 2004) and the parity as the important prerequisites for the biochemical indicators' interpretation in sheep. In order to establish the metabolic profile of the sheep, it is necessary to know the influence of reproductive status as well as the parity. In Ouled Djellal breed (main breed of sheep in Southeastern Algeria), information about the determination of normal biochemical and mineral values remain insufficient; therefore, the aim of this research is to show the changes of the serum mineral and biochemical indicators in the blood of ewes depending on reproductive status and the parity.

\section{MATERIALS AND METHODS}

\section{Choice of farms and animals}

Investigations were carried out on farms located in the agricultural region of El Doucen, in the Algerian Southeast arid area. This region is characterized by a dry climate, low rainfall, an average summer temperature of $42^{\circ} \mathrm{C}$ and dry pastures.

The choice of these farms was made on the basis of availability of information on studied animals, and the presence of a large number of sheep.

The study involved 100 multiparous and primiparous ewes of Ouled Djelal breed; animals were divided into three ewe groups: $P$ (pregnant $n=34$ ), $L$ (lactating $n=33$ ) and $E($ empty $n=33$ ).

\section{Sampling and analysis of blood samples}

Blood samples were taken from the jugular vein into dry and heparinized tubes; the operation took place in the morning (7:00 am) before food intake. Analysis concerned biological constants (glucose, cholesterol, triglycerides, urea, total protein, and albumin) as well as, [calcium $(\mathrm{Ca})$, phosphates $\left(\mathrm{PO}_{4}\right)$, sodium $(\mathrm{Na})$, potassium (K), and magnesium (Mg)]. These analysis were performed by spectrophotometer (BOEHINGER5010).

\section{Statistical analysis}

Data statistical analysis was performed using Epi Info software (version 6.04, 2003)

\section{RESULTS}

The lowest blood glucose values are in pregnant ewes, and in multiparous ones, the study showed statistical significant differences $(P<0.05)$ between ewes: (pregnant versus empty), and (lactating versus empty), however, these values remain within the range of international standards cited by most authors (Nelson and Guss, 1992; Radostits et al., 2000; Brugere-Picoux, 2002; Dubreuil et al., 2005) Table 1.

Cholesterol levels for the various batches are relatively lower than the standards cited by Brugere-Picoux (2002), and Ndoutamia and Ganda (2005).

However, the highest cholesterol levels were observed in lactating and primiparous sheep, those levels still within the limits of values reported by these authors.

The statistical study revealed no significant differences between different batches. Our animals have relatively lower triglyceride values than those described by Ndoutamia and Ganda (2005); however, they remain within the range of standard values referenced by Mollereau et al. (1995). The statistical study showed a significant difference $(p<0.05)$ between ewes: (lactating versus empty) for triglycerides.

Uremia, proteinemia and albuminia rated among the various groups are within the standards described by the authors.

The comparison of urea mean levels showed highly significant differences $(p<0.0001)$ between ewes: (pregnant versus empty); (lactating versus empty) and also between the three batches: (pregnant versus lactating versus empty).

But the difference is not significant for total protein and albumin rates. Furthermore, the highest proteinemia levels were observed in pregnant and multiparous ewes, and the lowest among empty sheep.

Calcium and sodium levels obtained in our study were below the physiological standards cited by most authors (Jelinek et al,, 1996; Brugere-Picoux, 2002; Dubreuil et al., 2005), however, they remain within the range of values described by Baumgartner and Pernthaner (1994) for the calcium. The statistical study showed significant differences $(p<0.05)$ between ewes (pregnant versus lactating) Table 2.

The phosphatemia found in pregnant and in multiparous ewes were below the standards reported by most authors (Brugere-Picoux, 2002; Dubreuil et al., 2005).

Serum magnesium concentrations correspond to the standards reported in the literature, and the values recorded for potassium are within the range of international standards described by Brugere-Picoux (2002), but they are below the values reported by Jelinek et al. (1996), and Dubreuil et al. (2005).

In addition, the comparison of mean levels of serum phosphorus and potassium revealed significant differences $(p<0.05)$ between ewes (pregnant versus lactating), also highly significant differences $(p<0.01)$ were found for magnesium levels between ewes (lactating versus empty). In this study, no significant difference was found between the multiparous and primiparous ewes. 
Table 1. Biochemical indicators of ewes depending on the reproductive status and parity.

\begin{tabular}{|c|c|c|c|c|c|c|}
\hline $\begin{array}{l}\text { Biochemical } \\
\text { indicators }(g / L)\end{array}$ & $(1)+(2)$ & $\begin{array}{l}\text { Pregnant } \\
(\mathrm{n}=34)\end{array}$ & $\begin{array}{l}\text { Lactating } \\
(\mathrm{n}=33)\end{array}$ & $\begin{array}{c}\text { Empty } \\
(\mathrm{n}=33)\end{array}$ & $\begin{array}{c}\text { Multiparous } \\
(\mathrm{n}=51)\end{array}$ & $\begin{array}{c}\text { Primiparous } \\
(n=49)\end{array}$ \\
\hline Glucose & $0.42-0.76(1)$ & $0.39^{b_{*}} \pm 0.19$ & $0.41^{C_{*}} \pm 0.18^{*}$ & $0,47^{*} \pm 0.10$ & $0,39^{\text {ns* }} \pm 0.17$ & $0.43^{\star} \pm 0.20$ \\
\hline Cholesterol & $0.52-0.76(1)$ & $0.49^{n s *} \pm 0.19$ & $0.51^{*} \pm 0.21$ & $0,48^{\mathrm{ns} *} \pm 0.06$ & $0,48^{n s *} \pm 0.19$ & $0.56^{*} \pm 0.23$ \\
\hline Triglycerides & $0.50 \pm 0.19(2)$ & $0.34^{*} \pm 0.29$ & $0.35^{c_{\star \star}} \pm 0.20$ & $0,27^{\star} \pm 0.12$ & $0,34^{\mathrm{ns} *} \pm 0.23$ & $0.35^{*} \pm 0.30$ \\
\hline Urea & $0.20-0.30(1)$ & $0.29^{b, e_{* \star *}} \pm 0.09$ & $0.32^{c_{* \star * \star}} \pm 0.14$ & $0,19^{\star} \pm 0.05$ & $0,31^{\mathrm{ns} *} \pm 0.11$ & $0.29^{*} \pm 0.13$ \\
\hline Total protein & $60-79(1)$ & $67.17^{\star} \pm 74.02$ & $64,19^{*} \pm 15.40$ & $58,80^{\star} \pm 5.21$ & $67,48^{\text {ns* }} \pm 60.47$ & $59.78^{\star} \pm 24.03$ \\
\hline Albumin & $24-30(1)$ & $25.65^{\star} \pm 12.72$ & $24,54^{*} \pm 4.47$ & $23.13^{*} \pm 3.50$ & $25,33^{\text {ns* }} \pm 10.64$ & $24.56^{\star} \pm 6.90$ \\
\hline
\end{tabular}

(1)Brugere -Picoux (2002); (2) Ndoutamia and Ganda (2005). ${ }^{*} \mathrm{P}<0.05 ;{ }^{* *} \mathrm{P}<0.01$; ${ }^{* * *} \mathrm{P}<0.001$. ${ }^{\mathrm{a}}$, Différences (pregnant versus lactating); , différences (pregnant versus empty); ${ }^{c}$, différences (lactating versus empty); ${ }^{\text {d }}$, différences (multiparous versus primiparous); ${ }^{e}$, différences (pregnant versus lactating versus empty).

Table 2. Mineral indicators of ewes depending on the reproductive status and parity.

\begin{tabular}{|c|c|c|c|c|c|c|}
\hline $\begin{array}{l}\text { Mineral } \\
\text { indicators }\end{array}$ & $(1)+(2)$ & $\begin{array}{c}\text { Pregnant } \\
(\mathrm{n}=34)\end{array}$ & $\begin{array}{l}\text { Lactating } \\
(n=33)\end{array}$ & $\begin{array}{l}\text { Empty } \\
(n=33)\end{array}$ & $\begin{array}{c}\text { Multiparous } \\
(n=51)\end{array}$ & $\begin{array}{c}\text { Primiparous } \\
(n=48)\end{array}$ \\
\hline $\mathrm{Ca}(\mathrm{mg} / \mathrm{L})$ & $80-100(1)$ & $83.29^{a * *} \pm 14.32$ & $91.2^{*} \pm 11.58$ & $69.60^{*} \pm 4.27$ & $87.15^{\star} \pm 14.43$ & $86.94^{*} \pm 10.95$ \\
\hline $\mathrm{PO}_{4}(\mathrm{mg} / \mathrm{L})$ & $50-73(2)$ & $45.87^{a_{\star \star}} \pm 19.13$ & $54.41^{*} \pm 19.59$ & $55.86^{b_{*}} \pm 11.71^{*}$ & $48.59^{*} \pm 17.61$ & $54.52^{\star} \pm 25.79$ \\
\hline $\mathrm{Na}(\mathrm{mEq} / \mathrm{L})$ & $145(2)$ & $135.2^{a_{\star \star}} \pm 7.32$ & $130.6^{\star} \pm 10.75$ & $132.73^{*} \pm 10.14$ & $132.54^{\star} \pm 9.77$ & $134.76^{\star} \pm 7.66$ \\
\hline $\mathrm{K}(\mathrm{mEq} / \mathrm{L})$ & $4.5(4-5)(2)$ & $4.17^{a_{* *}} \pm 0.65$ & $4.46^{\star} \pm 0.47$ & $4.26^{\star} \pm 0.74$ & $4 . .34^{*} \pm 0.57$ & $4.19^{*} \pm 0.66$ \\
\hline $\mathrm{Mg}(\mathrm{mg} / \mathrm{L})$ & $17-29(1)$ & $22.77^{a \star \star \star} \pm 4.16$ & $18.95^{\star} \pm 5.85$ & $22.55^{*} \pm 1.95$ & $20.42^{*} \pm 5.56$ & $22.72^{\star} \pm 4.29$ \\
\hline
\end{tabular}

(1) Baumgartner and Pernthaner (1994); (2) Brugere-Picoux (2002).

\section{DISCUSSION}

Glucose level reported in sheep is between 35 and 45 $\mathrm{mg} / \mathrm{dl}$ (Nelson and Guss, 1992) and could be influenced by the physiological stage (Firat and Ozpinar, 1996) and diseases (Symonds et al., 1986; Ford et al., 1990). Our results highlight a significant influence $(p<0.01)$ of physiological stage on blood sugar which is consistent with the observations of Hamadeh et al. (1996) who concluded that it has lower values in pregnant ewes compared with lactating or empty ones, however, Firat and Ozpinar (1996) did not mention any significant difference in blood glucose during pregnancy or during lactation; this observation is supported also by Radostits et al. (2000), who reported lower values than those reported by Shetaewi and Daghash (1994).

In case of pregnancy toxemia, blood glucose levels are lower than $20 \mathrm{mg} / \mathrm{dl}$ (Nelson and Guss, 1992). Antunovié et al. (2004) noted high blood glucose in empty females compared to pregnant ones. This was also reported in cows (Otto et al., 2000), and in Sahal's goats studied by Sandabe et al. (2004).

The decrease in blood sugar during pregnancy can be explained by the increase of maternal glucose permeability and use by the foetus (Tontis and Zwahlen, 1987; Sahlu et al., 1995).

Our results are inconsistent with those of Balikci et al. (2007) who reported a gradual increase $(p<0.05)$ of cholesterol levels during pregnancy compared with values obtained at $45^{\text {th }}$ days postpartum. Hamadeh et al. (1996) and Al-Dewachi (1999) pointed a high cholesterol levels in pregnant ewes compared to empty ones. This observation is supported by other studies that have reported high cholesterol levels [high density lipoprotein (HDL)-cholesterol and very-low-density lipoprotein (VLDL)-cholesterol] in the end of gestation (Krajnicakova et al., 1993; Hamadeh et al., 1996; Nazifi et al., 2002).

Also, no significant difference in serum cholesterol has been reported between pregnant ewes and empty ones (Ozpinar and Firat, 2003; Tanaka et al., 2007).

Hamadeh et al. (1996) noted that ewes giving birth to two lambs presented higher cholesterol levels than the ones with a single lamb, the same result is reported by Balkici et al. (2007) at 100 and $150^{\text {th }}$ days of gestation.

Antunovie et al. (2002) spoke about insignificant increase in plasma cholesterol in non-pregnant females compared with lactating ones; in a later study, they reported a higher cholesterol levels in lactating females than empty ones (Antunovie et al., 2004) which is consistent with our results.

The increase in triglyceride levels among lactating females may be due to insulin, which plays a direct role in adipose tissue metabolism during pregnancy and its responsiveness is significantly reduced in ewes during late pregnancy (Jainudee and Hafez, 1994; Schlumbohm et al., 1997). The diminished responsiveness of the target 
tissue to insulin during late pregnancy predisposes the ewes to increase of cholesterol, triglyceride and lipoproteins concentrations (Schlumbohm et al., 1997).

Furthermore, Krajnicakova et al. (1993), Hamadeh et al. (1996), and Nazifi et al. (2002) have reported high levels of triglycerides during late gestation; a similar result is underscored by Balikci et al. (2007) who noted a significant increase $(p<0.05)$ of triglyceride levels during pregnancy compared to $45^{\text {th }}$ days post partum, On 100 and $150^{\text {th }}$ days of gestation, these rates were higher among ewes who had two lambs, on the other hand, Tanaka et al. (2007) found no significant difference of serum triglycerides during lactation or dry period.

West (1995) recorded higher uraemia in pregnant ewes than in lactating or empty ones; other authors have found no effect of pregnancy on uremia (Scott and Robinson, 1976; Brozostowski et al, 1996; Meziane 2001).

Furthermore, Antunovié et al. (2002) reported high serum concentrations of urea during the last trimester of gestation and during lactation. In a subsequent study, they described significant differences of uremia between empty and pregnant females (Antunovié et al., 2004).

Our results are supported by Antunovié et al. (2002) who reported high serum concentrations of total protein during the last trimester of gestation and during lactation the same result is also emphasized by El-Sherif and Assad (2001) and Meziane (2001), who described a significant increase of proteinemia in pregnant ewes, unlike Brozostowski et al. (1996) who showed a decrease in proteinemia during late gestation.

In our study, neither the physiological stage nor parity had effect on albumin. This result is in contradiction with observations made by Shetaewi and Daghash (1994) who showed a decrease in serum albumin during lactation compared to gestation.

Our results are consistent with those described by Elias and Shainkin-Kestenbaum (1990), who reported hypocalcaemia in ewes during late gestation; they attributed this to the increasing calcium needs of the foetus.

Also, according to Liesegang et al. (2006), the decrease of calcemia in females is probably explained by the loss of calcium during various reproductive stages.

However, we noted that the highest average levels is observed in the lactating ewes; this is in contradiction with the observations of Sykes and Field (1974), Alonso et al. (1997), and Antunovie et al. (2002), who noted higher serum calcium in ewes in late gestation compared with ewes in lactation.

Contrary to our results, Antunovié et al. (2002) described an increase in the concentration of sodium in pregnant and lactating ewes and a high serum levels of phosphate and potassium at the end of gestation; the latter could be attributed to metabolic disorders that may occur in this period and this may, in his turn lead to various pathological deviations of metabolites in the blood (Hajdarevié et al., 1989).

Barlet et al. (1971) noted that unlike what happens in cows and goats, ewes do not present a significant hypocalcemia nor hypophosphatemia after giving birth. Our results are in disagreement with Sansom et al. (1982) who reported that during late gestation in sheep a high concentration of serum magnesium levels, decrease towards lambing and 3 weeks postpartum.

This study showed that the physiological stage has a significant influence on serum levels of glucose, triglycerides, urea, and macronutrients: calcium, phosphates, sodium, potassium and magnesium; however, no effect of parity has been found in our research.

\section{REFERENCES}

Al-Dewachi OS (1999). Some biochemical constituents in the blood serum of pregnant Awassi ewes. Iraqi. J. Vet. Sci. 12:275-279.

Alonso AJ, De Teresa R, Garcia M, Gonzalez JR, Vallejo M (1997). The effects of age and reproductive status on serum and blood parameters in Merino breed sheep. J. Vet. Med. Assoc. 44:223-231.

Antunovié Z, Sencic D, Speranda M, Liker B (2002). Influence of the season and reproductive status of ewes on blood parameters. Small Rumin. Res. 45:39-44.

Antunovié Z, Peranda M, Steiner Z (2004). The influence of age and the reproductive status to the blood indicators of the ewes. Arch. Tierz., Dummerstorf 47(3):265-273.

Balikci E, Yildiz A, Gurdocgan F (2007). Blood metabolite concentrations during pregnancy and postpartum in Akkaraman ewes. Small Rumin. Res. 67:247-251

Barlet JP, Michel MC, Larvor P, Thériez M (1971). Calcémie, phosphatémie, magnésémie et glycémie comparées de la mère et du nouveau-né chez les ruminants domestiques (vache, chèvre, brebis). Ann. Biol. Anim. Biochem. Biophys. 11(3):415-426

Baumgartner W, and Pernthaner A (1994). Influence of age, season, and pregnancy upon blood parameters in Austrian Karakul sheep. Small Rumin. Res. 13:147-151.

Brozostowski H, Milewski S,Wasilewska A, Tanski Z (1996). The influence of the reproductive cycle on levels of some metabolism indices in ewes. Arch. Vet. Polonic. 35:53-62.

Brugere-Picoux J (2002). Maladies métaboliques des ruminants cours 2004. ENV. Alfort, France.

Dubreuil P, Arsenault J, Bélanger D (2005). Biochemical reference ranges for groups of ewes of different ages. Vet Rec. 2005 May 14;156(20):636-638.

El-Sherif MMA, Assad F (2001). Changes in some blood constituents of Barki ewes during pregnancy and lactation under semiarid conditions. Small Rumin. Res. 40:269-277.

Elias E, Shainkin-Kestenbaum R (1990).Hypocalcaemia and serum levels of inorganic $\mathrm{P}, \mathrm{Mg}$, parathyroid and calcitonin hormones in the last month of pregnancy in Awassi fat-tail ewes. Reproduction, Nutrition, Development; 30(6):693-699.

Firat A, Ozpinar A (1996). The study of changes in some blood parameters (glucose, urea, bilirubin, AST) during and after pregnancy in association with nutritional conditions and litter size in ewes. Tr. J. Vet. Anim. Sci. 20:387-393.

Ford EJ, Evans J, Robinson I (1990). Cortisol in pregnancy toxemia of sheep. Br. Vet. J. 146: 539-542.

Hajdarevié F, Lokvanci H, Muteveli T, Nezirovi N (1989). A clinical laboratory assessment of several biochemical and mineral parameters

of late pregnant ewes. XIV Savjetovanje-Nove i sav. Metode urazmnožavanju ovacai koza. Ohrid, Macedonia, pp. 71-78.

Hamadeh ME, Bostedt H, Failing K (1996). Concentration of metabolic parameters in the blood of heavily pregnant and nonpregnant ewes. Berliner Munchener Trierarztlichewo chenschrift 109(81-86):593605

Jainudee MR, Hafez ESE (1994). Gestation, prenatal physiology and parturition. In: Hafez, E.S.E. (Ed.), Reproduction in Farm Animals. 
Lea and Febiger, Philadelphia, pp. 247-283.

JELINEK P, GAJDUSEK S, ILLEK J (1996).Relationship between selected indicators of milk and blood in sheep. Small Ruminant Research 20:53-57.

KLINKON M, ZADNIK T (1997).An outline of the metabolic profile test (MPT) in small ruminants. Stočarstvo 51:449-454.

Krajnicakova M, Bekeova E, Heindrichovsky V, Maracek I (1993). Concentrations of total lipis, cholesterol and progesterone during oestrus synchronization and pregnancy in sheep. Vet. Med. 38:349357.

Liesegang A, Risteli J, Wanner M (2006). The effects of first gestation and lactation on bone metabolism in dairy goats and milk sheep. Small Rumin. Res Bone 38:794-802.

Meziane T (2001). Contribution à l'étude de l'effet de la salinité de l'eau de boisson et d'un régime à base de paille chez les brebis de race Ouled Djellal dans les hauts plateaux sétifiens. Thèse Doctorat (Constantine), P. 162.

Mollereau H, Porcher C, Nicolas E, Brion A (1995). Vade-Mecum du vétérinaire formulaire. Vétérinaire et pharmacologie, de P. 1672.

Nazifi S, Saeb M, Ghavami SM (2002). Serum lipid profile in Iranian fattailed sheep in late pregnancy, at parturition and during the postparturition period. J. Vet. Med. Ser. A. 49:9-12.

Ndoutamia G, Ganda K (2005). Détermination des paramètres hématologiques et biochimiques des petits ruminants du Tchad Revue Méd. Vét. 156(4):202-206

Nelson DR, Guss SB (1992). Metabolic and Nutritional Diseases Nutrition. Illinois and Pennsylvania State Universities, pp. 1-5.

Otto F, Vilela F, Harun M, Taylor G, Baggasse P, Bogin E (2000). Biochemical blood profile of Angoni cattle in Mozambique. Israel Veterinary Medical Association, .55 (3).

Ozpinar A, Firat A (2003). Metabolic profile of pre-pregnancy, pregnancy and early lactation in multiple lambing Sakýz ewes. 2 Changes in plasma progesterone, estradiol-17B and cholesterol levels. Ann. Nutr. Metab. 47:139-143.

PASTRANA R, McDOWELL LR, CONRAD JH, WILKINSON NS (1991a).Macromineral status of sheep in the Paramo region of Colombia. Small Rumin. Res. 5:9-21.

PASTRANA R, McDOWELL LR, CONRAD JH, WILKINSON NS (1991b).Mineral status of sheep in the Paramo region of Colombia. II. Trace minerals. Small Rumin. Res. 5:23-34.

Radostits OM, Gay CC, Blood DC, Hinchcliff KW (2000).Veterinary Medicine, 9th ed. Harcourt Publishers Ltd., London, pp. 1417-1420.

Sahlu T, Hart SP, Fernandez JM (1995). Nitrogen metabolism and blood metabolites in three goat breeds fed increasing amounts of protein. Small Rumin. Res. 10:281-292.
Sandabe U-K, Mustapha AR, Sambo EY (2004). Effect of pregnancy on some biochemical parameters in Sahel goats in semi-arid zones. Vet. Res. Commun, May, 28(4):279-85.

Sansom BF, Bunch KJ, Dew SM (1982). Change in plasma calcium, magnesium, phosphorous and hydroxyproline concentrations in ewes from twelve weeks before until three weeks after lambing. Br. Vet. J. 138:393-401

Schlumbohm C, Sporleder HP, Gurtler H, Harmeyer J (1997). The influence of insulin on metabolism of glucose, free fatty acids and glycerolin normo- and hypocalcaemic ewes during different reproductive states. Deutsch. Tier"arztl. Wochenschr 104:359-365.

Scott D, Robinson JJ (1976). Changes in the concentrations of urea, glucose and some mineral elements in the plasma of the ewe during induced parturition. Res. Vet. Sci. 20(3):346-347.

Shetaewi M, Daghash HA (1994). Effects of pregnancy and lactation on some biochemical components in the blood of Egyptian coarse-wool ewes. Inst. Vet. Med. J. 30:64-73.

Sormunen-Cristian R, Jauhiainen L (2001). Comparison of hay and silage for pregnant and lactating Finnish Landrace ewes. Small Rumin. Res. 39:47-57.

Symonds ME, Bryant MJ, Lomax MA (1986). The effect of shearing on the energy metabolism of the pregnant ewe. Br. J. Nutr., 56: 635-643.

Sykes AR, Field AC (1974). Seasonal changes in plasma concentrations of proteins, urea, glucose, calcium and phosphorus in sheep grazing a hill pasture and their relationship to changes in body composition. J. Agric. Sci. Camb. 83:161-116

Tanaka Y, Mori H. Tazaki A, Imai S, Shiina J , Kusaba A, Ozawa T, Yoshida T , Kimura N , Hayashi T , Kenyon PR, Blair H, Arai T (2007). Plasma metabolite concentrations and hepatic enzyme activities in pregnant Romney ewes with restricted feeding. Res. Vet. Sci. 85:17-21.

Tissier M, Theriez M (1978). Ovins, In Alimentation des ruminants, Ed. INRA Publications, Versailles, France. pp. 403-448.

Tontis A, Zwahlen R (1987). Pregnancy toxemia of small ruminants with special reference to pathomorphology. Tierarztl Prax. 15(1):25-29.

West HJ (1995). Maternal undernutrition during late pregnancy in sheep. Its relationship to maternal condition, gestation length, hepatic physiology and glucose metabolism. Br. J. Nutr. 75:593-605.121. 